\title{
ПРОЕКТУВАННЯ КОМП’ЮТЕРНОЇ СИСТЕМИ ДЛЯ ОЦІНЮВАННЯ КОНКУРЕНТОСПРОМОЖНОСТІ ІТ-ПІДПРИЕМСТВА
}

\begin{abstract}
Продукти та послуги, які надає IT-сфера, - невід’ємна частина сучасного життя. Щороку на ринку з'являються нові IT-підприємства, що прагнуть надавати якісні IT-послуги та продукти, однак тільки незначна частка 3 них може утриматись на висококонкурентному ринку. Конкурентоспроможність є критерієм, щзо найбільш повно відображає ефективність діяльності будьякого економічного суб'єкта, в тому числі IT-підприємства. Саме тому оцінюючи конкурентоспроможність IT- підприємства необхідною умовою є розробка механізму комплексної оцінки показників конкурентоспроможності. Основою дослідження є встановлення сутності, переваг та недоліків існуючих методів оиінювання конкурентоспроможності підприємств, які працюють в IT-сфері. В дослідженні робиться спроба розробити комп 'ютерну систему очінювання конкурентоспроможності таких підприємств з урахуванням їх технологічної та економічної специифіки через призму інструментів підвищення конкурентоспроможності IT-підприємства. Стійке підвищення конкурентоспроможсності IT-підприсмства може бути забезпечене тільки за умови довгострокового, безперервного і поступального вдосконалення всіх детермінантів конкурентоспроможності, тобто на основі комплексного підходу. Метою дослідження $\epsilon$ розробка концептуальної схеми комп'ютерної системи для діагностики конкурентоспроможності IT-підприємства з метою збільшення ефективності його функціонування у сучасних умовах. Дотримуючись алгоритму оцінки конкурентоспроможності $і$ обравщи метод, заснований на комплексному оцінюванні, можна отримати дійсно достовірну інформацію про стан ITпідприсмства $і$ вже застосовувати запропоновані методи підвищення конкурентоспроможності. Комп'ютерна система, в основі якої лежить модель предметної області, алгоритм оцінювання конкурентоспроможності на основі комплексної оцінки, може бути використана для розв'язку задачі оцінювання конкурентоспроможності IT-підприємства. Комп'ютерна система видаватиме кінцеву множину рекомендацій особі, щзо приймає рімення (ОПР), щуодо відповідності впливу факторів конкурентоспроможності на ефективність діяльності. ОПР має використовувати таку систему як засіб часткової автоматизації складного процесу оичнювання ефективності.
\end{abstract}

Ключові слова: ефективність діяльності, конкурентоспроможність, комплексний підхід, алгоритм оцінювання, комп 'ютерна система, автоматизація.

O.Е.ОГНЕВА

Херсонский национальный технический университет ORCID:0000-0001-6206-0285

\section{ПРОЕКТИРОВАНИЕ КОМПЬЮТЕРНОЙ СИСТЕМЫ ДЛЯ ОЦЕНКИ КОНКУРЕНТОСПОСОБНОСТИ ІТ-ПРЕДПРИЯТИЯ}

\begin{abstract}
Продукты и услуги, предоставляемые IT-сферою - неотъемлемая часть современной жизни. Ежегодно на рынке появляются новые IT-предприятия, стремящиеся предоставлять качественные ITуслуги и продукты, однако только незначительная часть из них может удержаться на высококонкурентном рынке. Конкурентоспособность является критерием, наиболее полно отражающим эффективность деятельности любого экономического субъекта, в том числе ITпредприятия. Именно поэтому оценивая конкурентоспособность IT-предприятия необходимым условием является разработка механизма комплексной оченки показателей конкурентоспособности. Основой исследования является установление сущности, преимуществ и недостатков существующих методов оценки конкурентоспособности предприятий, работающих в IT-сфере. В исследовании делается попьтка разработать компьютерную систему оценки конкурентоспособности таких предприятий с учетом их технологической и экономической специфики через призму инструментов повышения конкурентоспособности IT-предприятия. Стойкое повышение конкурентоспособности IT-предприятия может быть обеспечено только при условии долгосрочного, непрерывного и поступательного совершенствования всех детерминант конкурентоспособности, то есть на основе комплексного подхода. Целью исследования является разработка кониептуальной схемы компьютерной системы для диагностики конкурентоспособности IT-предприятия с иелью увеличения эффективности его функиионирования в современных условиях. следуя алгоритму оченки конкурентоспособности и выбрав
\end{abstract}


метод, основанный на комплексном оценивании, можно получить действительно достоверную информацию о состоянии IT-предприятия и применять предложенные методы повышения конкурентоспособности. Компьютерная система, в основе которой лежит модель предметной области, алгоритм оценки конкурентоспособности на основе комплексной оценки, может быть использована для решения задачи оченки конкурентоспособности IT-предприятия. Компьютерная система способна выдавать конечное множество рекомендаций лииу, принимающему решение (ЛПР), на соответствие влияния факторов конкурентоспособности на эффективность деятельности. ЛПР должно использовать такую систему как средство частичной автоматизаџии сложного процесса оценки эффективности.

Ключевые слова: эффективность деятельности, конкурентоспособность, комплексный подход, алгоритм оценки, компьютерная система, автоматизацияя.

O.OHNIEVA

Kherson National Technical University ORCID: 0000-0001-6206-0285

\section{DESIGN OF A COMPUTER SYSTEM FOR ASSESSING THE COMPETITIVENESS OF IT- ENTERPRISE}

IT-products and services are an integral part of modern life. Every year, new IT-companies appear on the market, striving to provide quality IT services and products, but only a minority of them can stay in a highly competitive market. Competitiveness is the criterion that most fully reflects the efficiency of any economic entity, including IT-companies. That is why assessing the competitiveness of an IT-enterprise is a necessary condition for the development of a mechanism for comprehensive assessment of competitiveness indicators. The basis of the study is to establish the nature, advantages and disadvantages of existing methods for assessing the competitiveness of enterprises operating in the IT-field. The study attempts to develop a computer system for assessing the competitiveness of such enterprises, taking into account their technological and economic specifics through the prism of tools to increase the competitiveness of IT-enterprises. A sustainable increase in the competitiveness of an IT-enterprise can be ensured only if the long-term, continuous and progressive improvement of all determinants of competitiveness, ie on the basis of an integrated approach. The aim of the study is to develop a conceptual scheme of a computer system for diagnosing the competitiveness of an IT-enterprise in order to increase the efficiency of its operation in modern conditions. following the algorithm of competitiveness assessment and choosing a method based on a comprehensive assessment, you can get really reliable information about the state of the IT-enterprise and already apply the proposed methods of improving competitiveness. A computer system based on a subject area model, a competitiveness assessment algorithm based on a comprehensive assessment, can be used to solve the problem of assessing the competitiveness of an IT-enterprise. The computer system will issue a finite set of recommendations to the decision maker (DM) on the appropriateness of the impact of competitiveness factors on performance. DM should use such a system as a means of partially automating a complex performance appraisal process.

Key words: performance efficiency, competitiveness, integrated approach, evaluation algorithm, computer system, automation.

\section{Постановка проблеми}

Новітні та інтернет-технології активно увійшли у життя людства, особливо їх необхідність та актуальність відчувається під час надзвичайних ситуацій, таких, як пандемія. Суспільство вже не може уявити своє існування без продуктів та програм, які надає IT-сфера $[1,4,5,8,12]$.

Щороку на ринку з'являються нові IT-підприємства, що прагнуть надавати якісні IT-послуги та продукти, однак тільки незначна частка 3 них може утриматись на висококонкурентному ринку. Сфера ITпослуг в Україні є однією з найперспективніших галузей української економіки, тому вона потребує постійного дослідження й аналізу конкурентоспроможності $[1,4,5,8,12]$.

Основою дослідження $є$ встановлення сутності, переваг та недоліків існуючих методів оцінювання конкурентоспроможності компаній, які працюють в IT-сфері. В дослідженні робиться спроба розробити комп'ютерну систему оцінювання конкурентоспроможності таких підприємств 3 урахуванням їх технологічної та економічної специфіки через призму інструментів підвищення конкурентоспроможності ІТ-підприємства.

Аналіз останніх досліджень і публікацій

Питання конкурентоспроможності підприємства та ефективності функціонування підприємства досліджено у великій кількості робіт таких вітчизняних та зарубіжних вчених, як: Л.Балабанової, В.Виборнова, Г.Азоєва, Ю.Іванова, А.Прокопчук, І.Падеріна, Л.Піддубної, В.Подсолонко, В.Шинкаренка, 
І.Отенко, Г.Асселя, І.Ансоффа, Ф.Котлера, Г.Минцберга, М.Портера, Ф.Тейлора, А.Сміта, А.Файоля та інших.

Тему розвитку IT-послуг було розглянуто такими співвітчизниками, як І.Мавріна, А.Мокроносов, М..Рахман, Ю.Тарануха. Внесок в дослідження розвитку ІТ-ринку зробили такі дослідники, як О.Бабанін, А.Барбаш, О.Булкот, К.Козьменко, І.Матвій та інші.

Дослідженню питань функціонування IT-сфери та їі впливу на економіку України присвячено праці таких вітчизняних вчених, як О.Бабанін, С.Войтко, В.Глухов, А.Маслов, А.Могилова, С.Пиріг, І.Седікова, Л.Федулова, М.Чайковська, А.Чухно та інші.

Однак, аналіз публікацій вітчизняних та зарубіжних вчених свідчить, що на даний час невирішеними залишається ряд питань, які стосуються проблем конкурентоспроможності IT- підприємств на сучасному ринку та перспектив його розвитку в Україні. Вони залишаються недостатньо розкритими та потребують подальшого опрацювання. Недостатня розробленість зазначеного питання, його актуальність та практичне значення визначили мету даного дослідження.

\section{Формулювання мети дослідження}

Конкурентоспроможність є критерієм, що найбільш повно відображає ефективність діяльності будь-якого економічного суб'єкта, в тому числі ІТ-підприємства. Обгрунтування методів оцінки конкурентоспроможності ІТ-підприємства, з точки зору визначення його ефективності, використання комп'ютерних систем $\epsilon$ набагато складнішим завданням, аніж виявлення напрямів конкурентоспроможності підприємств. Проблема діагностики конкурентоспроможності IT-підприємств 3 метою збільшення ефективності його функціонування в сучасних умовах стає все актуальнішою.

Метою дослідження є розробка концептуальної схеми комп'ютерної системи для діагностики конкурентоспроможності IT-підприємства 3 метою збільшення ефективності його функціонування у сучасних умовах.

\section{Викладення основного матеріалу дослідження}

Для України IT-сфера має особливо важливе значення, тому що навіть на фоні загальної економічної кризи, вона здатна згладити ці явища за допомогою стрімкого розвитку, а також забезпечення функціонування багатьох суміжних галузей. За відносно короткий проміжок часу IT-сфера перетворилась на один з головних драйверів світової економіки, ставши каталізатором для тектонічних змін i трансформацій у багатьох інших індустріях $[1,4,5,8,12]$.

Відповідно до цього, у ІТ-підприємств виникає активна необхідність пошуку нових механізмів, інструментів та методів для забезпечення та оцінювання їхньої конкурентної роботи. Дослідження конкурентоспроможності українських IT-підприємств в епоху розвинених технологій $\epsilon$ перспективним напрямом, оскільки ця галузь із кожним роком збільшується і приносить дохід в ВВП країни. Тому аналіз конкурентоспроможності українських IT-підприємств дасть можливість розвивати IT-сферу в Україні.

Категорії послуг та продуктів ІТ-підприємств зазвичай охоплює три великі сфери: апаратного забезпечення, яка включає промислове, серверне та користувацьке обладнання; програмного забезпечення (ПЗ), яка включає корпоративне ПЗ, ПЗ інформаційної безпеки та ПЗ із відкритим кодом; IT-послуг, яка включає аутсортинг, ІТ-консультування та обробку та зберігання електронної інформації [7, 11 12].

Конкурентоспроможність підприємства - це відносна характеристика, яка виражає ступінь відмінності даного підприємства від конкурентів у сфері задоволення потреб клієнтів. Висока конкурентоспроможність підприємства обумовлюється задоволеністю і готовністю споживачів повторно придбати продукцію та послуги цього підприємства, відсутністю претензій до підприємства 3 боку суспільства, акціонерів, партнерів, престижністю роботи на даному підприємстві [7, 11 12].

Рівень конкурентоспроможності характеризує стан підприємства, що визначає перспективи його подальшого розвитку, можливість досягнення стратегічних цілей та завдань. Ефективність функціонування підприємства, зокрема його здатність відповідати високим вимогам ринку, якість задоволення споживчого попиту та ресурсний потенціал $є$ основними факторами, що визначають конкурентоспроможність підприємства на ринку [7, 11 12].

Оцінити конкурентоспроможність підприємства означає здійснити розрахунки комплексу показників, що характеризують різні аспекти діяльності підприємства та стан ринкового середовища, оцінити їх рівень та інтерпретувати отримані результати.

Існує багато методів оцінки конкурентоспроможності підприємств. При цьому жоден 3 них не можна вважати ідеальним, у кожного є свої позитивні і негативні сторони. Питання інструментарію оцінювання конкурентоспроможності суб'єктів господарювання є одним із найактуальніших, пов'язаних із проблемами їхнього виживання і розвитку в умовах ринку $[3,7,11]$.

Вибір методу або методів є індивідуальним для кожного IT-підприємства і його визначають завдання, які йому потрібно вирішити (діагностика стану підприємства, вибір стратегії та ін.), рівень ухвалення рішення та фактори конкурентного середовища.

Класифікація методів оцінки конкурентоспроможності підприємства передбачає їх поділ на окремі групи за певною ознакою (рис.1) $[3,7,12]$. 


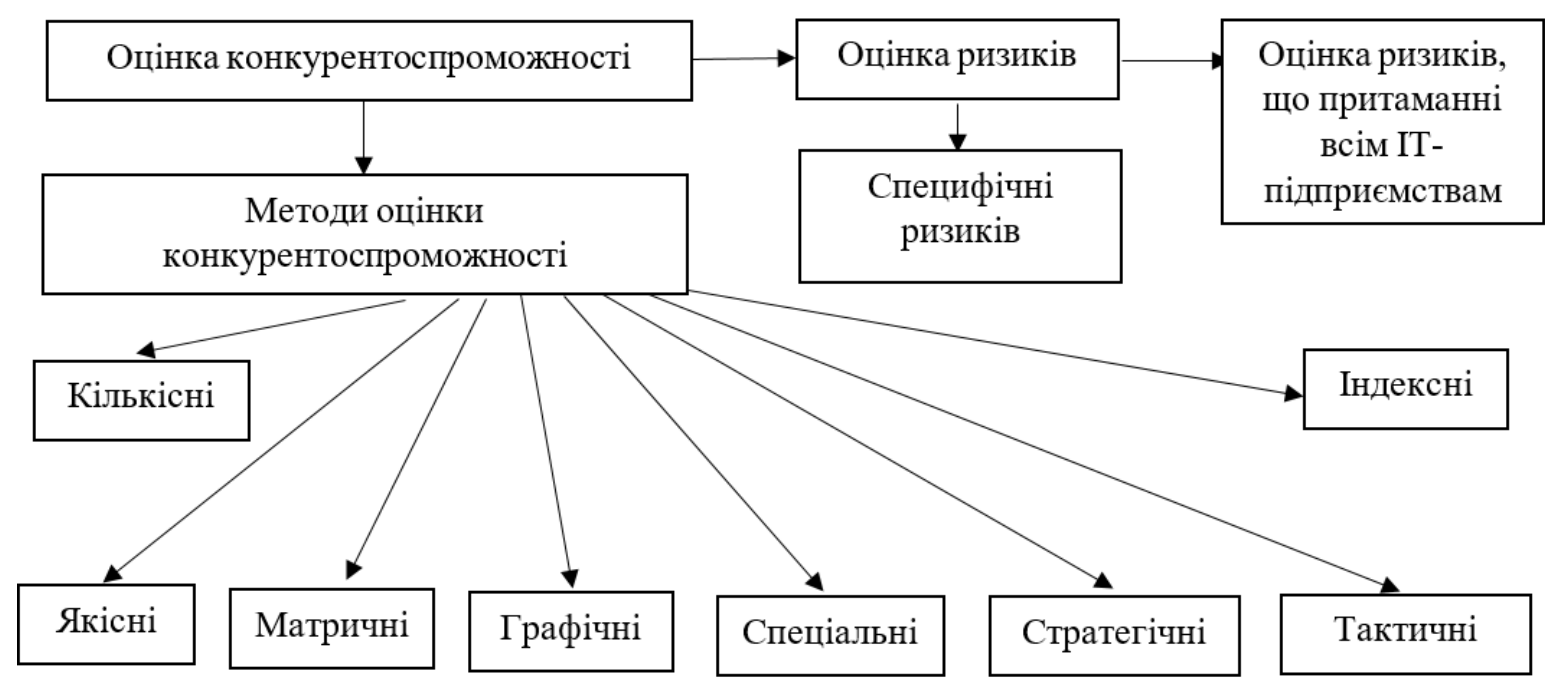

Рис.1. Класифікація методів оцінки конкурентоспроможності IT-підприємства

В якості інструменту підвищення конкурентоспроможності IT-підприємства також розглядається оцінка ризиків. Посилення конкурентної позиції компанії неможливе без зниження (мінімізації) ризиків, що притаманні її діяльності (рис.1)[7, 9].

Типологізація та ідентифікація ризиків є одними з основних компонентів заходів побудови системи управління ними. Незважаючи на те, що повністю вилучити їх неможливо, управлінський персонал IT-підприємства має розробити та впровадити заходи для зменшення ймовірності їх виникнення та мінімізації наслідків (рис.1). Класифікація ризиків спрямована на використання насамперед облікового механізму управління ризиками $[7,9]$.

Комплексні ж методи полягають у комплексному підході і передбачають аналіз усього спектра найважливіших параметрів функціонування підприємства. Завдяки цим методам можна отримати найточнішу інформацію про конкурентоспроможність підприємства на основі досить широкого переліку порівняльних переваг, врахувати параметри як внутрішнього, так і зовнішнього середовища $[3,7,9,11$, $12]$.

Загальна модель прийняття рішень на підприємстві при комплексному оцінюванні конкурентоспроможності може бути представлена наступним чином:

$S^{\prime}=\{S, M, A, E, D, X, G\}$,

де $S^{\prime}$ - множина ситуацій, що виникають в результаті оцінювання конкурентоспроможності;

$S$ - множина вихідних ситуацій за видами оцінок конкурентоспроможності;

$M$ - множина моделей розвитку ситуацій

$M=\left\{M_{1}, M_{2}\right\}$,

де $M_{1}$ - множина ситуацій для методів оцінки конкурентоспроможності підприємства,

$M_{2}$ - множина ситуацій для методів оцінки ризиків;

$A$ - множина альтернатив розвитку ситуації за методами оцінювання конкурентоспроможності;

$E$ - множина критеріїв оцінки ефективності рішень за методами;

$D$ - множина рішень за методами;

$X$ - множина станів об'єкта;

$G$ - мета управління об'єктом.

Задача комплексного оцінювання конкурентоспроможності підприємства полягає у виборі оптимальної траєкторії функціонування підприємства, при якій багатоцільова функція виду $\operatorname{extr}_{U} F_{1}, \ldots, F_{k}$ досягає найкращого значення за умови виконання системи обмежень для методів оцінювання конкурентоспроможності. 


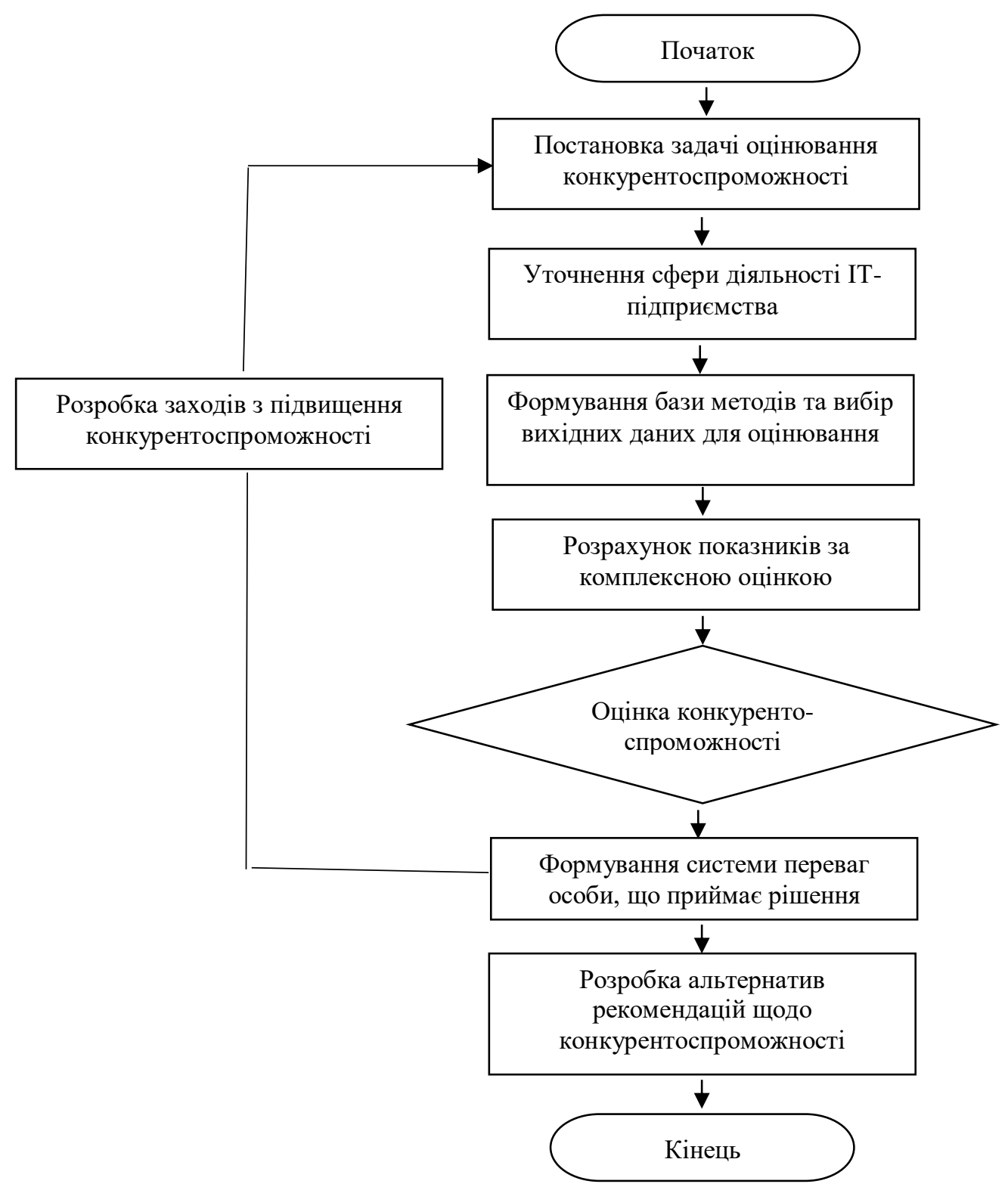

Рис.2. Алгоритм комплексного оцінювання конкурентоспроможності IT-підприємств

Задача комплексного оцінювання конкурентоспроможності підприємства полягає у виборі оптимальної траєкторії функціонування підприємства, при якій багатоцільова функція виду $\operatorname{extr}_{U} F_{1}, \ldots, F_{k}$ досягає найкращого значення за умови виконання системи обмежень для методів оцінювання конкурентоспроможності.

$F_{k}=\psi(U, S, A)-k$-ий вектор цільових показників задачі оцінювання конкурентоспроможності. $U=(U 1, \ldots, U T)$ - траєкторії управляючих змінних, $A$ й $S$ - екзогенні та ендогенні траєкторії параметрів зовнішнього і внутрішнього середовища підприємства з усіх видів діяльності.

Саме тому оцінюючи конкурентоспроможність IT- підприємства необхідною умовою є розробка механізму комплексної оцінки показників конкурентоспроможності, алгоритм якого наведено на рис.2.

Отже, дотримуючись алгоритму оцінки конкурентоспроможності і обравши метод, заснований на комплексному оцінюванні, можна отримати дійсно достовірну інформацію про стан IT-підприємства і вже застосовувати запропоновані методи підвищення конкурентоспроможності.

Ключовою передумовою формування конкурентних переваг $\epsilon$ наявність конкуренції, яка $\epsilon$ основним спонукальним мотивом для здійснення економічним суб'єктом діяльності щодо пошуку нових властивостей, які вигідно відрізняють його від конкурентів.

Розробка механізму оцінки конкурентоспроможності IT-підприємства потребує збору та обробки великого масиву інформації щодо характеристик типів суб'єктів, їх можливих дій у різних умовах функціонування, оптимальних дій для досягнення цільової функції механізму тощо. Окрім того, 
передбачається, що такий механізм буде знаходитись у динамічних умовах, де прогнозовані дії економічних суб'єктів можуть доповнюватись. Така громіздка науково-дослідна діяльність потребує окремої наукової узагальнюючої оцінки з відповідним набором методичних підходів.

Комп'ютерна система, в основі якої лежить модель предметної області, алгоритм оцінювання конкурентоспроможності якої наведено на рис.1, може бути використана для розв'язку задачі оцінювання конкурентоспроможності IT-підприємства.

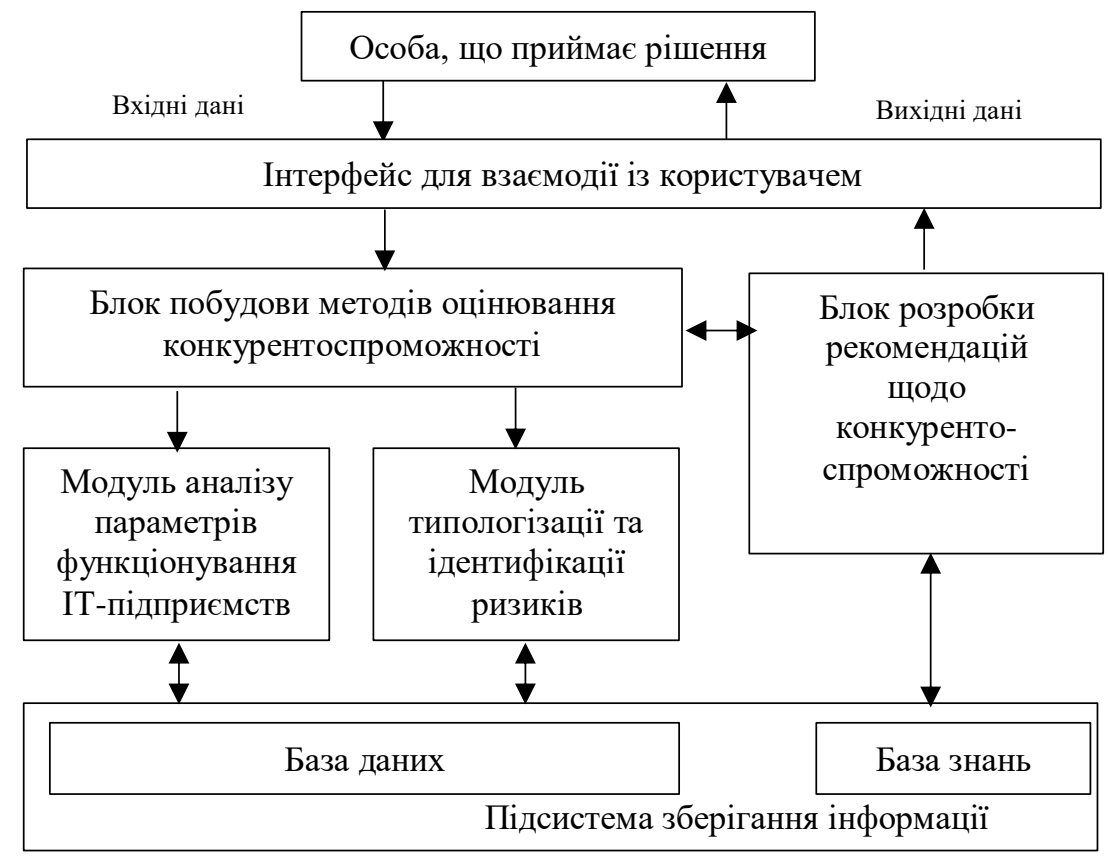

\section{Рис.3. Концептуальна схема комп'ютерної системи комплексного оцінювання конкурентоспроможності IT-підприємства}

Комп’ютерна система, концептуальна схема якої наведена на рис.3, видаватиме кінцеву множину рекомендацій особі, що приймає рішення, щодо відповідності впливу факторів конкурентоспроможності на ефективність його діяльності. ОПР має використовувати таку систему як засіб часткової автоматизації складного процесу оцінювання ефективності.

При використанні методів оцінки конкурентоспроможності необхідний диференційований підхід, при чому найбільш повну інформацію можна одержати, використовуючи одночасно декілька методів оцінки. Однак, застосування більшості з них зіштовхується із труднощами збору даних, відсутністю необхідної дослідницької підготовки фахівців та іншими факторами.

IT-сектор продовжує залишатися одним з найбільш динамічних сегментів економіки України. Сьогодні технології оточують нас у всіх сферах життя, при цьому відкривається багато нових ITпідприємств, зарубіжні компанії теж заходять на український ринок інформаційних технологій та відкривають власні офіси, конкуренція в ІТ-сфері також зростає кожного року.

Питання оцінювання конкурентоспроможності IT-підприємства потребують грунтовного вивчення. Відомі методи поодинці не задовольняють вимог українських IT-підприємств, оскільки залишається невирішеним питання вибору універсального показника та факторів конкурентоспроможності, що визначають його рівень.

Стійке підвищення конкурентоспроможності IT-підприємства може бути забезпечене тільки за умови довгострокового, безперервного i поступального вдосконалення всіх детермінантів конкурентоспроможності, тобто на основі комплексного підходу.

Позитивні тенденції розвитку ІТ-сфери вимагають проведення подальших досліджень, спрямованих на формування підходів до оцінки конкурентоспроможності таких підприємств. У результаті застосування до оцінки процесу підвищення конкурентоспроможності комплексного оцінювання до показників, що впливають на активізацію діяльності з формування конкурентних переваг IT-підприємства, як сукупність стимулів, обмежень і потреб, які впливають на прийняття рішень його керівництвом [5-6, $12]$.

Подальші дослідження можуть бути орієнтовані на обгрунтування та відпрацювання системи управлінських заходів загального характеру, відповідних механізмів, що можуть бути запроваджені за результатами використання комплексного методу оцінки конкурентоспроможності IT-підприємства та на удосконалення комп’ютерної системи. 
Новітні досягнення у IT-сфері особливо актуальні й для ІТ-підприємств. Як свідчить практика, будь-яка комп'ютерна система підприємства в сучасних умовах успішно функціонує лише при її інтеграції 3 передовими новітніми та інтернет-технологіями, які стають одним з основних інструментів підвищення ефективності діяльності в сучасних ринкових умовах. Застосування новітніх інструментів об'єктивне зумовлене такими чинниками, як подальша глобалізація економіки України, перехід до європейських і світових стандартів тощо. Подальшому розвитку і шляхам підвищення конкурентоспроможності ITпідприємств є побудова нового технологічного рішення для реалізації комп’ютерних систем за допомогою хмарних технологій, що набувають дедалі більш широких обертів, відповідно питання їх застосування для оцінювання конкурентоспроможності IT-підприємства є актуальними на сьогодні [2,10].

\section{Висновки}

1. На підставі аналізу літературних джерел було з'ясовано, що найбільш об'єктивну оцінку конкурентоспроможності можна отримати за допомогою комплексної методики. Комплексна методика оцінки конкурентоспроможності IT-підприємств становить порівняно простий інструмент для практичного застосування.

2. Використання комп'ютерної системи на основі комплексного оцінювання, концептуальну схему якої запропоновано, дозволить ОПР обрати математично обгрунтовані рішення.

3. Застосування новітнього інструментарію у комп'ютерної системі оцінки конкурентоспроможності дозволить у подальшому отримати новітнє технологічне рішення.

\section{Список використаної літератури}

1. Вікулова А.О. Перспективи розвитку ринку ІТ-послуг в Україні / А.О.Вікулова, В.В.Савчук // Причорноморські економічні студії. - 2020. - Вип. 51. - С. 27-32

2. Волот O.І. Застосування хмарних технологій в обліку та управлінні підприємствами реального сектору економіки / О. І. Волот // Центральноукраїнський науковий вісник. Економічні науки. - 2019. Вип. 2. - С. 190-198

3. Гудкова К. Ю. Методи та підходи до оцінки ефективності ІТ-проектів / К.Ю.Гудкова, А.О.Лях // Економічний вісник Донбасу. - 2016. - № 3. - С. 193-196. - Режим доступу: http://nbuv.gov.ua/UJRN/ecvd_2016_3_29

4. Довгань Л. Є. Тенденції та проблеми розвитку сфери інформаційних технологій в Україні: кадрові аспекти / Л. Є. Довгань, І. П. Малик // Економічний вісник Національного технічного університету України "Київський політехнічний інститут". - 2017. - № 14. - С. 437-443. Режим доступу: http://nbuv.gov.ua/UJRN/evntukpi_2017_14_69

5. Журавльов О. В. Статистичне дослідження ринку ІТ-послуг в Україні / О.В.Журавльов, О.А.Сімачов // Статистика України. - 2018. - № 4. - С. 25-33. - Режим доступу: http://nbuv.gov.ua/UJRN/su_2018_4_5

6. Казакова Н. А. Ставка України на розвиток ІТ-індустрії / Н.А.Казакова, О.А.Марушева, Є.Е.Широкорад // Вісник Харківського національного університету імені В.Н. Каразіна. - 2017. - Вип. 6. C. $43-49$

7. Кваско А.В. Аналіз методів оцінки конкурентоспроможності підприємства / А.В.Кваск // Економічні науки. Наукові записки. - 2017. - № 1 (54). - С. 111-118

8. Купріянова В.С. Аналіз і перспективи розвитку підприємницького аутсорсингу в IT-галузі України / В.С.Купріянова, Г.М. Шведова //Підприємництво та інновації. - 2020.- Вип.12. - C.59-63 DOI: https://doi.org/10.37320/2415-3583/12

9. Нечаєва I.А. Управління ризиками підприємства в секторі IT-послуг як інструмент підвищення його конкурентоспроможності / І.А.Нечаєва, С.А.Дьордій // Ефективна економіка. - 2018. - № 12. - - Режим доступу: http://www.economy.nayka.com.ua/?op=1\&z=6797. DOI: 10.32702/2307-2105-2018.12.120

10. Параниця Н. В. Переваги і ризики застосування хмарних технологій в сфері бухгалтерського обліку / Н.В.Параниця, О.С.Буличов, О.М.Охмак // Економіка та держава. - 2021. - № 4. - С. $128-131$. DOI: $10.32702 / 2306-6806.2021 .4 .128$

11. Рахман М.С. Конкуренція та конкурентоспроможність IT-підприємств на міжнародному ринку / М.С.Рахман, А.О.Александрова // Науковий вісник Херсонського державного університету. Серія: Економічні науки. - 2018. - Вип. 30(1). - С. 26-29. - Режим доступу: http://nbuv.gov.ua/UJRN/Nvkhdu_en_2018_30(1)_7

12. Чижов В.А. Проблеми та перспективи управління IT-компаніями в умовах соціально-економічної кризи України / В.А.Чижов // Економіка та держава. - 2016. - № 9. - С. 68-71

\section{References}

1. Vikulova A., Savchuk V. Perspektyvy rozvytku rynku IT-posluh v Ukraini [The perspectives of the IT services market development in Ukraine]. Prychornomorski ekonomichni studii [Black Sea Economic Studies], 2020, no 51, pp/ 27-32 
2. Volot O. Zastosuvannia khmarnykh tekhnolohii v obliku ta upravlinni pidpryiemstvamy realnoho sektoru ekonomiky [Application of the cloud technologies in accounting and management of enterprises of the real sector of economy]. Tsentralnoukrainskyi naukovyi visnyk. Ekonomichni nauky [Central Ukrainian Scientific Bulletin. Economic sciences], 2019, no 2, pp. 190-198

3. Gudkova E., Lyakh A. Metody ta pidkhody do otsinky efektyvnosti IT-proektiv [Methods and approaches to evaluating the effectiveness of IT projects]. Ekonomichnyi visnyk Donbasu [Economic Bulletin of Donbass], 2016, no 3, pp.193-196. available at: http://nbuv.gov.ua/UJRN/ecvd_2016_3_29.

4. Dovgan L., Malik I. Tendentsii ta problemy rozvytku sfery informatsiinykh tekhnolohii v Ukraini: kadrovi aspekty [Trends and challenges of IT industry in Ukraine: HR aspects]. Ekonomichnyi visnyk Natsionalnoho tekhnichnoho universytetu Ukrainy "Kyivskyi politekhnichnyi instytut". [Economic Bulletin of the National Technical University of Ukraine "Kyiv Polytechnic Institute], 2017, no 14, pp. 437- 443, available at: http://nbuv.gov.ua/UJRN/evntukpi_2017_14_69

5. Zhurauliou A.V., Simachov O.A. Statystychne doslidzhennia rynku IT-posluh v Ukraini [Statistical Analysis of the IT Market in Ukraine]. Statystyka Ukrainy [Statistics of Ukraine], 2018, no 83 (4), pp. 25-33

6. Shirokorad Y., Kazakova N., Marusheva O. Stavka Ukrainy na rozvytok IT-industrii [The ukrainian bet on IT-industry development]. Visnyk Kharkivskoho natsionalnoho universytetu imeni V.N.Karazina [Bulletin of Kharkiv National University named after VN Karazina], 2017, no 6, pp.43-49

7. Kvasko A.V. Analiz metodiv otsinky konkurentospromozhnosti pidpryiemstva [Analysis of methods of estimation of enterprise competitiveness]. Ekonomichni nauky. Naukovi zapysky [Economic sciences. Scientific papers], no 1(54), pp. 111-118

8. Kupriianova V.S., Shvedova H.M. Analiz i perspektyvy rozvytku pidpryiemnytskoho autsorsynhu v IThaluzi ukrainy [Analysis and prospects for the development of entrepreneurial outsourcing in the IT industry]. Pidpryiemnytstvo ta innovatsii [Intrepreneurship and innovation], 2020, no 12, pp.59-63. DOI: https://doi.org/10.37320/2415-3583/12.

9. Nechayeva I., Dordiy E. Upravlinnia ryzykamy pidpryiemstva v sektori IT-posluh yak instrument pidvyshchennia yoho konkurentospromozhnosti [Risk management of the enterprise in the it service sector as an instrument for improving it competitiveness]. Efektyvna ekonomika Efficient economy], 2018, no 12, available at: http://www.economy.nayka.com.ua/?op=1\&z=6797. DOI: 10.32702/2307-2105-2018.12.120

10. Paranytsia N., Bulychov O., Okhmak, O. Perevahy i ryzyky zastosuvannia khmarnykh tekhnolohii v sferi bukhhalterskoho [Advantages and risks of application of cloud technologies in the field of accounting]. Ekonomika ta derzhava [Economy and state], 2021, no 4, pp. 128-131. DOI: 10.32702/2306-6806.2021.4.128

11. Rakhman M.S. Konkurentsiia ta konkurentospromozhnist IT-pidpryiemstv na mizhnarodnomu rynku [Competition and competitiveness of IT companies in the international market]. Naukovyi visnyk Khersonskoho derzhavnoho universytetu. Seriia: Ekonomichni nauky [Scientific Bulletin of Kherson State University. Series: Economic Sciences], 2018, no 30(1), pp.26-29, available at: http://nbuv.gov.ua/UJRN/Nvkhdu_en_2018_30(1)_7.

12. Chyzhov V. Problemy ta perspektyvy upravlinnia IT-kompaniiamy v umovakh sotsialno-ekonomichnoi kryzy Ukrainy [Problems and perspectives of IT companies management under the socio-economic crisis in Ukraine]. Ekonomika ta derzhava [Economy and state], 2016, no 9, pp. 68-71. 